\title{
Microstructure and Mechanical Properties of Mo-Si-Al Alloy and Mo-Si-Al/SiC Composite
}

\author{
Yoshikazu Suzuki, Atsushi Nakahira, Tohru Sekino and Koichi Niihara \\ The Institute of Scientific and Industrial Research, Osaka University, 8-1 Mihogaoka, Ibaraki 567.
}

Received December 1, 1995

\section{SYNOPSIS}

$\mathrm{Mo}-\mathrm{Si}-\mathrm{Al}$ alloy and $\mathrm{Mo}-\mathrm{Si}-\mathrm{Al} / \mathrm{SiC}$ composite were fabricated by the powder metallurgical process from a novel Mo-Si-Al prealloyed powder, and their microstructure and mechanical properties were evaluated. The Mo-Si-Al and Mo-Si-Al/15 vol\%SiC mixed powders were hot-pressed in an argon atmosphere. XRD analyses revealed that $\mathrm{Mo}-\mathrm{Si}-\mathrm{Al} / \mathrm{SiC}$ composites were composed of $\mathrm{MoSi}_{2}$ (tetragonal, $\mathrm{Cl1} 1_{\mathrm{b}}$ structure), $\mathrm{Mo}(\mathrm{Si}, \mathrm{Al})_{2}$ (hexagonal, C40 structure), $\alpha-\mathrm{Al}_{2} \mathrm{O}_{3}, \mathrm{Mo}_{55} \mathrm{Si}_{3} \mathrm{C}_{51}$ and $\beta-\mathrm{SiC}$. Almost no glassy $\mathrm{SiO}_{2}$ phase was found in $\mathrm{Mo}-\mathrm{Si}-\mathrm{Al}$ and Mo-Si-Al/SiC systems contrary to $\mathrm{MoSi}_{2}$ and $\mathrm{MoSi}_{2} / \mathrm{SiC}$. The formation of $\alpha-\mathrm{Al}_{2} \mathrm{O}_{3}$ was attributed to the predominant oxidation of aluminum at the surface of the $\mathrm{Mo}-\mathrm{Si}-\mathrm{Al}$ prealloyed powder. Mo-Si-Al based systems showed the better high-temperature strength mainly due to the elimination of glassy $\mathrm{SiO}_{2}$ and the crystallographical change from t-MoSi, to h-Mo( $\left.\mathrm{Si}, \mathrm{Al}\right)_{2}$. Incorporation of fine $\mathrm{SiC}$ particles enabled to control microstructure and then to enhance mechanical properties.

\section{KEY WORDS}

$\mathrm{MoSi}_{2}, \mathrm{Mo}(\mathrm{Si}, \mathrm{Al})_{2}$, Mo-Si-Al/SiC composite, mechanical properties, $\mathrm{Al}_{2} \mathrm{O}_{3}$ formation

\section{Introduction}

Molybdenum disilicide $\left(\mathrm{MoSi}_{2}\right)$ is a promising material for various applications such as aerospace exposed to temperatures more than $1500^{\circ} \mathrm{C}$, mainly because of its high melting point $\left(2030^{\circ} \mathrm{C}\right)$ and fairly good oxidation resistance. However, its fracture toughness and strength are not high enough for high-temperature structural applications. Furthermore, glassy $\mathrm{SiO}_{2}$ which is present in the metallurgically produced $\mathrm{MoSi}_{2}$ powder strongly degrades the high-temperature mechanical properties $^{1)}$. Thus, main efforts have focused on improving mechanical properties of this material. Especially, "second phase dispersion ${ }^{2-8) " ~ a n d ~ " S i O ~}$ elimination 9-14)" have been widely investigated.

Recently "alloying" has been also adapted to improve various properties of $\mathrm{MoSi}_{2} .{ }^{15-16)} \mathrm{Mo}-\mathrm{Si}-\mathrm{Al}$ is one of the most fascinating system because of its good cyclic oxidation resistance ${ }^{16-17)}$ and of crystallographical modification from tetragonal $\mathrm{Cll}_{\mathrm{b}}$ structure of $\mathrm{MoSi}_{2}$ to hexagonal $\mathrm{C} 40$ of $\mathrm{Mo}(\mathrm{Si}, \mathrm{Al})_{2}{ }^{18-19)}$ Silva et al. ${ }^{20-22)}$ reported that elemental $\mathrm{Al}$ addition enabled to convert $\mathrm{SiO}_{2}$ to $\mathrm{Al}_{2} \mathrm{O}_{3}$ in powder processed $\mathrm{MoSi}_{2}$. This "in-situ displacement reaction" technique controls $\mathrm{Al}$ content easely. However, using fine $\mathrm{Al}$ metal powder is sometimes disadvantageous; fine Al metal is flammable and it has relatively high vapor pressure during heating.

In this investigation, a novel Mo-Si-Al prealloyed powder was used to fabricate Mo-Si-Al alloys. In order to control microstructure and to improve mechanical properties, fine $\mathrm{SiC}$ particles reinforced alloys were also fabricated. High temperature strength as well as room temperature mechanical properties was evaluated for $\mathrm{Mo}-\mathrm{Si}-\mathrm{Al}$ and $\mathrm{Mo}-\mathrm{Si}-\mathrm{Al}$ /SiC composites.

\section{Experimental procedure}

The novel Mo-Si-Al powder was supplied by Japan New Metals Co., Ltd. It was fabricated from elemental powders of molybdenum ( $>99.9 \mathrm{wt} . \%$ ), silicon (>99.75 wt.\%) and aluminum (99.65 wt.\%). The elemental powders (nominal composition; $\mathrm{MoSi}_{1.72} \mathrm{Al}_{0.28}$ ) were mixed, heated for solid state reaction, crushed and then sieved. The result of chemical analysis of the powder is shown in 
Table 1. Since aluminum and silicon have high vapor pressure, the obtained powder became Morich compared with the stoichiometric composition. From the standpoint of mechanical properties, however, such deviation is rather favorable; if elemental $\mathrm{Al}$ and $\mathrm{Si}$ were remained in the materials, mechanical properties, especially high-temperature strength, will drop down. Spectrochemical analysis revealed that the major impurities were 0.82 wt.\% oxygen, 0.09 wt.\% carbon and 0.08 wt.\% iron. For the composite, a commercial $\beta$-SiC powder (Mitsui Toatsu Chemical Co., Ltd.) was added $15 \%$ by volume. The $\mathrm{SiC}$ starting powder contained less impurities than the Mo-Si-Al powder as indicated in Table 1. Mean particle sizes of the Mo-Si-Al powder and the $\beta$-SiC powder were 1.61 and $0.15 \mu \mathrm{m}$, respectively.

Table 1 Chemical analyses of Mo-Si-Al (left) and $\mathrm{SiC}$ (right) powders.

\begin{tabular}{|c|c|c|c|c|}
\hline & \multicolumn{2}{|c|}{ Content } & & Content \\
\hline & (wt.\%) & (at.\%) & $\mathrm{SiC}$ & $>99$ (wt.\%) \\
\hline Mo & 63.39 & 33.15 & $\mathrm{iO}_{2}$ & 0.15 (wt.\%) \\
\hline $\mathrm{Si}$ & 31.15 & 55.64 & tree-C & 0.10 (wt.\%) \\
\hline Al & 4.41 & 820 & Al & $\begin{array}{r}120(\mathrm{ppm}) \\
48(\mathrm{nnm})\end{array}$ \\
\hline $\mathrm{O}$ & 0.82 & 2.57 & $\mathrm{Ca}$ & $40(\mathrm{ppm})$ \\
\hline C & 0.09 & 0.38 & $\mathrm{Mg}$ & 10 (ppm) \\
\hline $\mathrm{Fe}$ & 0.08 & 0.07 & $\begin{array}{l}\mathrm{Cr} \\
\mathrm{Ni}\end{array}$ & $20(\mathrm{ppm})$ \\
\hline
\end{tabular}

They were mixed by wet ball-milling in 1-butanol with $\mathrm{ZrO}_{2}$ balls for $24 \mathrm{~h}$, and then the dried mixture was dry-ball-milled to crush the agglomerations. Mo-Si-Al with/without $\mathrm{SiC}$ powders were packed into carbon dies which were coated with $\mathrm{BN}$ and then hot-pressed at $1500^{\circ} \mathrm{C}$ for $\mathrm{Mo}-\mathrm{Si}-\mathrm{Al}$ and at $1600^{\circ}$ $\mathrm{C}$ for the composite under an applied pressure of 30 MPa for $1 \mathrm{~h}$ in an argon atmosphere. The sintered disks were $44 \mathrm{~mm}$ in diameter and $5.0 \mathrm{~mm}$ in thickness. The hot-pressed bodies were cut, grounded and polished into rectangular bars with $4 \times 3 \times 36$ $\mathrm{mm}$ in size.

Phase identification was carried out by the $\mathrm{X}$-ray diffraction (XRD) analysis, and bulk densities were measured by the Archimedes method in toluene. Microstructure was characterized by scanning electron microscopy (SEM, HITACHI S-5000) with an energy dispersive $\mathrm{X}$-ray spectrometer (EDS,
HORIBA EMAX-5770). Samples for SEM observations were pre-coated with $\mathrm{Au}$. More than five specimens were subjected to three-point bending tests (span: $30 \mathrm{~mm}$ ) to determine the fracture strength. Bending load was applied parallel to hotpress axis with a crosshead speed of $0.5 \mathrm{~mm} / \mathrm{min}$. The hardness $(H)$ was evaluated by Vickers indentation under a condition of $98 \mathrm{~N}$ load and loading duration of $15 \mathrm{~s}$, and the fracture toughness $\left(K_{\mathrm{IC}}\right)$ was determined simultaneously by the indentation fracture (IF) method. $K_{\text {IC }}$ values were calculated by using the following empirical equation for a median $\operatorname{crack}^{23)}$.

$K_{\text {IC }}=0.203(c / a)^{-3 / 2} H \cdot a^{1 / 2}$

where $c$ and $a$ are the lengths of a median crack and half of a diagonal of a indentation, respectively.

\section{Results and discussion}

\subsection{Chemistry and phase identification}

Fig.1 shows XRD patterns for (a) Mo-Si-Al prealloyed powder, (b) Mo-Si-Al hot-pressed at $1500^{\circ} \mathrm{C}$ and (c) Mo-Si-A1/15vol\%SiC composite hot-pressed at $1600^{\circ} \mathrm{C}$, respectively. XRD revealed that Mo-Si-Al alloy was composed of $\mathrm{MoSi}_{2}$ (tetragonal, ${\mathrm{C} 11_{\mathrm{b}}}_{\text {structure), }} \mathrm{Mo}(\mathrm{Si}, \mathrm{Al})_{2}$ (hexagonal, $\mathrm{C} 40$ structure), $\alpha-\mathrm{Al}_{2} \mathrm{O}_{3}$ and $\mathrm{Mo}_{s 5} \mathrm{Si}_{3} \mathrm{C}_{\leq 1}$. For the composite, $\beta$-SiC was identified in addition to above mentioned phases. The formation of $\alpha-\mathrm{Al}_{2} \mathrm{O}_{3}$ was attributed to predominant oxidation of aluminum ${ }^{17)}$ at surfaces of the Mo-Si-Al precursor powder. $\mathrm{Mo}_{s s}$ $\mathrm{Si}_{3} \mathrm{C}_{\leq 1}$ is the only stable Mo-Si-C ternary phase; called the Nowotny phase ${ }^{24)}$. The formation of $\mathrm{Mo}_{\leq s}$ $\mathrm{Si}_{3} \mathrm{C}_{\leq 1}$ phase was ascribed to (1) the deviation from the stoichiometric composition of the Mo-Si-Al powder and (2) the presence of carbon arising from the impurity of powders as well as that from ball milling and hot-pressing processes. From Table 1, the composition of the Mo-Si-Al powder was calculated (Table 2). The calculation was made assuming that phases in the powder were $\mathrm{Cl}_{b}$, $\mathrm{C} 40, \mathrm{Mo}_{5} \mathrm{Si}_{3}, \alpha-\mathrm{Al}_{2} \mathrm{O}_{3}$, free carbon and $\mathrm{Fe}_{2} \mathrm{O}_{3}$. $\mathrm{C}_{1} 1_{\mathrm{b}}$ and $\mathrm{C} 40$ were not distinguished in the calculation because $\mathrm{C} 11_{\mathrm{b}} / \mathrm{C} 40$ ratio is subject to change; $\mathrm{MoSi}_{2}$ dissolves $\mathrm{Al}$ up to about 3 at.\% and the range of $\mathrm{Al}$ composition in $\mathrm{Mo}(\mathrm{Si}, \mathrm{Al})_{2}$ is about 10 to 35 at.\%. ${ }^{15,17)}$ Some carbon may dissolve in $\mathrm{Mo}_{5} \mathrm{Si}_{3}$ to form $\mathrm{Mo}_{\leq 5} \mathrm{Si}_{3} \mathrm{C}_{\leq 1}$. After hot-pressing, it 
is considered that the content of $\mathrm{MoSi}_{2}$ and $\mathrm{Mo}_{5} 5$ $\mathrm{Si}_{3} \mathrm{C}_{\leq 1}$ should increase and that of $\mathrm{Mo}(\mathrm{Si}, \mathrm{Al})_{2}$ should decrease because of the high vapor pressure of $\mathrm{Al}$ at high temperatures. Hence, the change of the phase ratio was clearly observed from (100) of $\mathrm{Mo}(\mathrm{Si}, \mathrm{Al})_{2}$ at $2 \theta \fallingdotseq 22.1^{\circ}, \quad(002)$ of $\mathrm{MoSi}_{2}$ at $2 \theta \doteqdot 22.6^{\circ}$ and (200) of $\mathrm{Mo}_{\leq 5} \mathrm{Si}_{3} \mathrm{C}_{\leq 1}$ at $2 \theta \doteqdot 28.2^{\circ}$ in Fig. 1 .

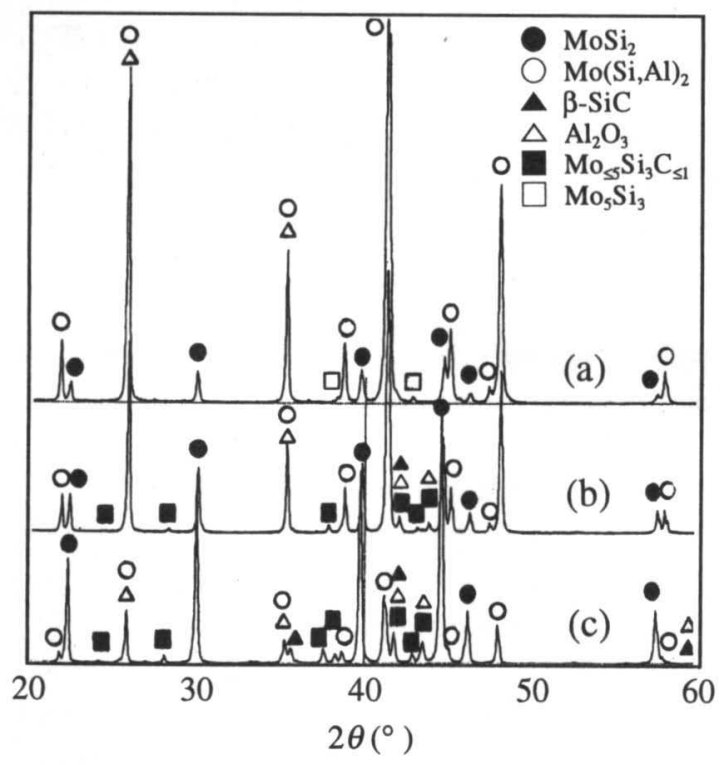

Fig.1 X-ray diffraction patterns for (a)Mo-Si-Al powder, (b)Mo-Si-Al (c)Mo-Si-Al/15 vol\% $\mathrm{SiC}$ composite.

Table 2 Calculated composition of the Mo-Si-Al powder.

\begin{tabular}{lccccc}
\hline & $\begin{array}{c}\text { Matrices } \\
\left(\mathrm{C} 11_{\mathrm{b}}+\mathrm{C} 40\right)\end{array}$ & $\mathrm{Mo}_{5} \mathrm{Si}_{3}$ & $\mathrm{Al}_{2} \mathrm{O}_{3}$ & free-C & $\mathrm{Fe}_{2} \mathrm{O}_{3}$ \\
\hline $\begin{array}{l}\text { Content } \\
\text { (mol\%) }\end{array}$ & 94.32 & 1.83 & 2.56 & 1.17 & 0.11 \\
\hline
\end{tabular}

\subsection{Microstructure}

Figs.2(a) and 2(b) show backscattered electron images taken by SEM for the Mo-Si-Al and the $\mathrm{Mo}-\mathrm{Si}-\mathrm{Al} / \mathrm{SiC}$ composite, respectively. As seen from Fig.2 (a), four phases were identified in the Mo-Si-Al alloy; EDS analysis revealed that phases which appear dark $(\alpha)$, relatively dark $(M)$, relatively bright $\left(M^{\prime}\right)$ and bright $(\mathrm{N})$ were $\alpha-\mathrm{Al}_{2} \mathrm{O}_{3}$, $\mathrm{MoSi}_{2}, \mathrm{Mo}(\mathrm{Si}, \mathrm{Al})_{2}$ and $\mathrm{Mo}_{s 5} \mathrm{Si}_{3} \mathrm{C}_{\leq 1}$, respectively. In combination with polarized optical microscopy observations, it was revealed that the smaller $\alpha-\mathrm{Al}_{2} \mathrm{O}_{3}$ phase $(\sim 1 \mu \mathrm{m})$ had a nearly round shape and located within matrix grains and at grain boundaries, especially at triple points. This microstructure formation may be explained as follows; The Mo-Si-Al powder had the oxidized layer (i.e. $\alpha-\mathrm{Al}_{2} \mathrm{O}_{3}$ ) on the surfaces and a thin $\mathrm{Mo}_{5} \mathrm{Si}_{3}$ region below the $\alpha-\mathrm{Al}_{2} \mathrm{O}_{3}$ layer. ${ }^{17,25)}$ During hot-pressing, $\alpha-\mathrm{Al}_{2} \mathrm{O}_{3}$ was concentrated mainly at triple points, and carbon impurity dissolved in $\mathrm{Mo}_{5} \mathrm{Si}_{3}$ to form $\mathrm{Mo}_{\leq 5}$ $\mathrm{Si}_{3} \mathrm{C}_{\leq 1}$. In the $\mathrm{Mo}-\mathrm{Si}-\mathrm{Al} / \mathrm{SiC}$ system, on the other hand, four domains were observed as shown in Fig.2(b); domains appearing dark ( $\left.\alpha^{\prime}\right)$, relatively dark $(\mathrm{M})$, relatively bright $\left(\mathrm{M}^{\prime}\right)$ and bright $(\mathrm{N})$ were $\alpha-\mathrm{Al}_{2} \mathrm{O}_{3} / \mathrm{SiC}, \mathrm{MoSi}_{2}, \mathrm{Mo}(\mathrm{Si}, \mathrm{Al})_{2}$ and $\mathrm{Mo}_{\leq 5} \mathrm{Si}_{3} \mathrm{C}_{\leq 1}$, respectively. It is considered that a large portion of $\mathrm{SiC}$ particles was trapped by $\mathrm{Al}_{2} \mathrm{O}_{3}$ during hotpressing. Table 3 summarizes appeared phases in $\mathrm{MoSi}_{2}$-based materials in the presence of carbon. ${ }^{14,26)}$ Grain sizes of matrices were $6.5 \mu \mathrm{m}$ for Mo-Si-Al and $2.2 \mu \mathrm{m}$ for Mo-Si-Al/SiC composite. This suggests that added $\mathrm{SiC}$ particles effectively inhibit matrix grain growth .
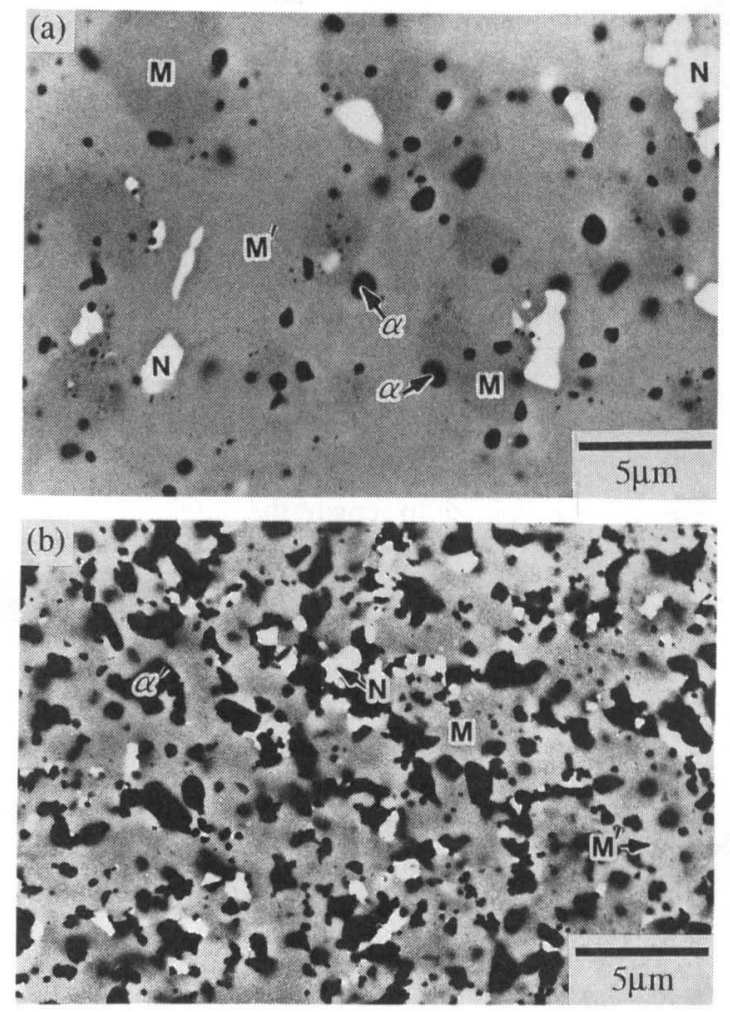

Fig.2 Backscattered electron images for (a)Mo-Si$\mathrm{Al}$ and (b)Mo-Si-Al/15 vol\% SiC composite; M: $\mathrm{MoSi}_{2}, \mathrm{M}^{\prime}: \mathrm{Mo}(\mathrm{Si}, \mathrm{Al})_{2}, \alpha: \alpha-\mathrm{Al}_{2} \mathrm{O}_{3}, \alpha^{\prime}$ : $\alpha-\mathrm{Al}_{2} \mathrm{O}_{3} / \mathrm{SiC}$ and $\mathrm{N}: \mathrm{Mo}_{\leq 5} \mathrm{Si}_{3} \mathrm{C}_{\leq 1}$. 
Table 3 Appeared phases in the presence of carbon.

\begin{tabular}{ll}
\hline Samples & \multicolumn{1}{c}{ Microstructure } \\
\hline $\mathrm{MoSi}_{2}{ }^{14,26)}$ & $\mathrm{C} 11_{\mathrm{b}}+\mathrm{g}-\mathrm{SiO}_{2}{ }^{*}+\mathrm{Mo}_{\leq 5} \mathrm{Si}_{3} \mathrm{C}_{\leq 1}$ \\
$\mathrm{MoSi}_{2} / \mathrm{SiC}{ }^{26)}$ & $\mathrm{C} 11_{\mathrm{b}}+\mathrm{g}-\mathrm{SiO}_{2}{ }^{*}+\mathrm{Mo}_{\leq 5} \mathrm{Si}_{3} \mathrm{C}_{\leq 1}+\mathrm{SiC}$ \\
$\mathrm{Mo}-\mathrm{Si}-\mathrm{Al}$ & $\mathrm{C} 11_{\mathrm{b}}+\mathrm{C} 40+\alpha-\mathrm{Al}_{2} \mathrm{O}_{3}+\mathrm{Mo}_{\leq 5} \mathrm{Si}_{3} \mathrm{C}_{\mathrm{s}}$ \\
$\mathrm{Mo}-\mathrm{Si}-\mathrm{Al} / \mathrm{SiC}$ & $\mathrm{C} 11_{\mathrm{b}}+\mathrm{C} 40+\alpha-\mathrm{Al}_{2} \mathrm{O}_{3}+\mathrm{Mo}_{\leq 5} \mathrm{Si}_{3} \mathrm{C}_{\leq 1}+\mathrm{SiC}$ \\
\hline
\end{tabular}

${ }^{*} \mathrm{~g}-\mathrm{SiO}_{2}:$ glassy $\mathrm{SiO}_{2}$

\subsection{Room temperature properties}

To clarify the effect of the microstructural modification on mechanical properties, hardness, strength and toughness were examined. Table 4 shows average matrix grain size and room temperature mechanical properties for $\mathrm{MoSi}_{2}$ fabricated from coarse powder ${ }^{27)}, \mathrm{MoSi}_{2}$ from fine powder ${ }^{4,14,26)}$, $\mathrm{MoSi}_{2} / 15 \mathrm{vol} \% \mathrm{SiC}$ composite ${ }^{4,26)}$, Mo-Si-Al alloy and $\mathrm{Mo}-\mathrm{Si}-\mathrm{Al} / 15 \mathrm{vol} \% \mathrm{SiC}$ composite.

\section{Alloying effect}

In order to clarify the alloying effect, the results from finer $\mathrm{MoSi}_{2}$ and $\mathrm{Mo}-\mathrm{Si}-\mathrm{Al}$ were compared. Although Mo-Si-Al has somewhat larger grain size, its hardness and strength were higher than those of $\mathrm{MoSi}_{2}$. Harada et. $\mathrm{al}^{15)}$ have briefly described the hardness of $\mathrm{Al}$-alloyed $\mathrm{MoSi}_{2}$ fabricated by using arc melting; the hardness was decreasing with increasing the $\mathrm{Al}$ content in the range of $0-10$ at.\% (i.e. $\mathrm{MoSi}_{2}$ to $\mathrm{MoSi}_{1.7} \mathrm{Al}_{0.3}$ ) and then increasing with increasing it in the range of $10-15$ at.\% (i.e. $\mathrm{MoSi}_{1.7} \mathrm{Al}_{0.3}$ to $\mathrm{MoSi}_{1.55} \mathrm{Al}_{0.45}$ ). $\quad \mathrm{Cl1}_{\mathrm{b}}$ dissolved $\mathrm{Al}$ up to 3 at.\% and single phase $\mathrm{C} 40$ appeared more than 10 at.\% Al. They explained that the decrement of hardness was due to the solid solution "softening" (i.e. Al into Si-site of $\mathrm{Cl}_{\mathrm{b}}$ ) and the increment was due to the crystallographical modification (i.e. $\mathrm{C}_{\mathrm{b}} \mathrm{b}_{\mathrm{b}}$ to $\mathrm{C} 40$ ). For powder metallurgically processed systems, however, other phases which are dispersing in alloys affect the hardness in addition to above mentioned mechanisms. Although $\mathrm{C} 11_{\mathrm{b}}$ phase should be softened by dissolving $\mathrm{Al}$ (up to $3 \mathrm{at} . \%)^{15}$ ), $\mathrm{Al}_{2} \mathrm{O}_{3}$ and $\mathrm{Mo}_{55} \mathrm{Si}_{3} \mathrm{C}_{\leq 1}$ dispersion should give hardening effect. Combination of these opposite effects, the hardness value of Mo-Si-Al was a little higher than that of $\mathrm{MoSi}_{2}$. As for strength, the strengthening was mainly due to the $\mathrm{Al}_{2} \mathrm{O}_{3}$ formation instead of glassy $\mathrm{SiO}_{2}$. On the contrary to hardness and strength, the toughness value of Mo-Si-Al was slightly smaller than that of $\mathrm{MoSi}_{2}$. This was because the intragranular fracture was dominant for $\mathrm{Mo}-\mathrm{Si}-\mathrm{Al}$ in contrast with $\mathrm{MoSi}_{2}$; both inter- and intragranular fracture was observed for $\mathrm{MoSi}_{2}$. Furthermore, the change of intrinsic bonding strength may affect the toughness.

\section{Combination of alloying and dispersion}

It has been reported that $\mathrm{SiC}$ dispersion is fairly effective to enhance mechanical properties of $\mathrm{MoSi}_{2} \cdot{ }^{2-4,26)} \quad$ Alloying and composite techniques were simultaneously adapted to obtain better mechanical properties. The Mo-Si-Al/15vol\%SiC system possessed relatively fine grain size and fairly high mechanical properties, especially for hardness. The hardening was due to the hard phases (i.e. $\mathrm{Al}_{2} \mathrm{O}_{3}, \mathrm{Mo}_{\leq 5} \mathrm{Si}_{3} \mathrm{C}_{\leq 1}$ and $\mathrm{SiC}$ ) dispersion, the grain growth inhibition and the decrease of solid solution softening effect with decreasing total $\mathrm{Al}$ content. The strengthening was mainly attributed to the grain growth inhibition, and the toughening was caused by residual stress induced by thermal expansion mismatch. ${ }^{4.26)}$

Table 4 Room temperature mechanical properties of Mo-Si based materials.

\begin{tabular}{|c|c|c|c|c|c|}
\hline & $\begin{array}{c}T \\
\left({ }^{\circ} \mathrm{C}\right)\end{array}$ & $\begin{array}{c}d \\
(\mu \mathrm{m})\end{array}$ & $\underset{(\mathrm{GPa})}{H_{\mathrm{V}}}$ & $\begin{array}{c}\sigma_{\mathrm{f}} \\
(\mathrm{MPa})\end{array}$ & $\begin{array}{c}K_{\mathrm{IC}}^{*} \\
(\mathrm{MPa} \sqrt{\mathrm{m}})\end{array}$ \\
\hline $\left.\mathrm{MoSi}_{2}(\text { coarse })^{27}\right)$ & 1700 & $10-20$ & $8-10$ & $\sim 250$ & $2-3$ \\
\hline $\mathrm{MoSi}_{2}(\text { fine })^{4,14,26)}$ & 1500 & 5.2 & 10.38 & 687 & 2.29 \\
\hline $\mathrm{MoSi}_{2} / 15 \% \mathrm{SiC}^{4,26)}$ & 1500 & 2.1 & 12.44 & 1216 & 3.09 \\
\hline Mo-Si-Al & 1500 & 6.5 & 10.98 & 764 & 1.92 \\
\hline Mo-Si-Al/15\%SiC & 1600 & 2.2 & 14.21 & 1107 & 3.00 \\
\hline
\end{tabular}

* $T$ : hot-pressing temperature, $d$ : average matrix grain size,

$H_{\mathrm{V}}$ :hardness, $\sigma_{\mathrm{f}}$ : fracture strength, $K_{\mathrm{IC}}$ : fracture toughness

\subsection{High temperature strength}

High temperature strength was evaluated in order to examine the alloying and $\mathrm{SiC}$ dispersion effects and to confirm the usefulness of Mo-Si-Al. Fig.3 shows the variation of strength with temperature for $\mathrm{MoSi}_{2}$ from coarse powder ${ }^{28)}, \mathrm{MoSi}_{2}$ from fine powder ${ }^{26}, \mathrm{MoSi}_{2} / \mathrm{SiC}$ composite ${ }^{26}, \mathrm{Mo}-\mathrm{Si}-\mathrm{Al}$ and $\mathrm{Mo}-\mathrm{Si}-\mathrm{Al} / \mathrm{SiC}$ composite. Although the strength values of fine $\mathrm{MoSi}_{2}$ and $\mathrm{MoSi}_{2} / \mathrm{SiC}$ composite were fall down more than $1000^{\circ} \mathrm{C}, \mathrm{Mo}-\mathrm{Si}-\mathrm{Al}$ and $\mathrm{Mo}-$ $\mathrm{Si}-\mathrm{Al} / \mathrm{SiC}$ composite kept high strength values up to $1100^{\circ} \mathrm{C}$. The strength values at $1100^{\circ} \mathrm{C}$ were 833 $\mathrm{MPa}$ for $\mathrm{Mo}-\mathrm{Si}-\mathrm{Al}$ and $954 \mathrm{MPa}$ for $\mathrm{Mo}-\mathrm{Si}-\mathrm{Al} / \mathrm{SiC}$ 
composite. The improvement on high-temperature strength was mainly due to the glassy $\mathrm{SiO}_{2}$ elimination. It is concluded that alloying with $\mathrm{Al}$ was fairly effective to enhance mechanical properties not only at room temperature but also at high temperatures.

It is worthy of note that alloying with aluminum enabes us to control microstructure, i.e. elimination of glassy $\mathrm{SiO}_{2}$ and crystallographical modification from $\mathrm{C} 11_{b}$ to $\mathrm{C} 40$. This approach may be available to other silicides.

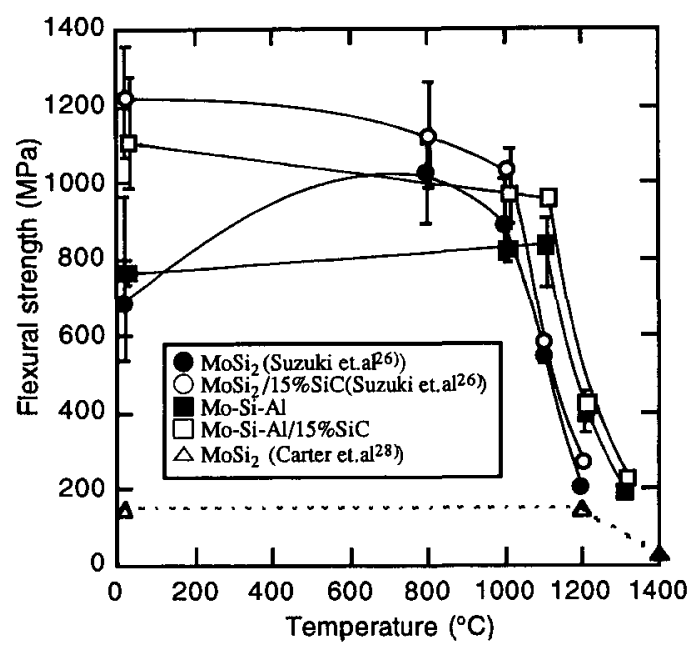

Fig.3 Variation of strength with temperature for $\mathrm{MoSi}_{2}$-based materials.

\section{Conclusions}

The present work reveals microstructure and mechanical properties of the Mo-Si-Al alloy and the Mo-Si-Al/SiC composite. The results are summarized as follows;

1. Mo-Si-Al alloy and Mo-Si-Al/SiC composite were fabricated by the powder metallurgical process from a novel prealloyed powder. The alloy was composed of $\mathrm{MoSi}_{2}, \mathrm{Mo}(\mathrm{Si}, \mathrm{Al})_{2}, \alpha-\mathrm{Al}_{2} \mathrm{O}_{3}$ and $\mathrm{Mo}_{\leq 5}$ $\mathrm{Si}_{3} \mathrm{C}_{s 1}$. The composite was composed of these four phases and $\beta-S i C$. The intergranular glassy $\mathrm{SiO}_{2}$ phase could be changed into thermodynamically stable $\alpha-\mathrm{Al}_{2} \mathrm{O}_{3}$ by the alloying.

2. Mechanical properties such as hardness and strength were enhanced by alloying. Combination of alloying and composite techniques, hardness, strength, toughness and high-temperature strength were simultaneously improved.
3. These results indicate that the combination of alloying and composite techniques has great advantages to fabricate $\mathrm{MoSi}_{2}$-based materials with wellbalanced mechanical properties. Further optimization of fabrication conditions will enable to improve the mechanical properties of $\mathrm{MoSi}_{2}$-based system.

\section{Acknowledgments}

The authors gratefully acknowledge to Japan New Metals Co., Ltd. for the kind provision of powder used. This research was financially supported in part by the Ministry of Education, Science, Sports and Culture, Japan, Grant-in Aid for Science Research Nos.03555157 and 06555195.

\section{References}

1) R. B. Schwarz, S. R. Srinivasan, J. J. Petrovic and C. J. Maggiore: Mater. Sci. Eng., A155 (1992) 75 .

2) F. D. Gac and J. J. Petrovic: J. Am. Ceram. Soc., 68 (1985) C200.

3) K. K. Richardson and D. W. Freitag: Ceram. Eng. Sci. Proc., 12 (1991) 1679.

4) Y.Suzuki, A. Nakahira, T. Sekino and K. Niihara: Ceramic Transactions, vol.44, American Ceramic Society, Westerville, Ohio, 1994, 427.

5) J. J. Petrovic and R. E. Honnell: J. Mater. Sci., 25 (1990) 4453.

6) J. J. Petrovic, R. E. Honnell, T. E. Mitchell, R. K. Wade and K. J. McClellan: Ceram. Eng. Sci. Proc., 12 (1991) 1633.

7) R. G. Castro, R. W. Smith, A. D. Rollett and P. W. Stanec: Scripta. Metall. Mater., 26 (1992) 207.

8) L.Shaw and R. Abbaschian: Acta Metall. Mater., 42 (1994) 213.

9) S. A. Maloy, A. H. Heuer, J. J. Lewandowski, and J. J. Petrovic: J. Am. Ceram. Soc., 74 (1991) 2704.

10) S. A. Maloy, J. J. Lewandowski, A. H. Heuer and J. J. Petrovic: Mater. Sci. Eng., A155 (1992) 159.

11) N. S. Jacobson, K. N. Lee, S. A. Maloy and A. H. Heuer: J. Am. Ceram. Soc., 76 (1993) 2005.

12)D. K. Patrick and D. C. Van Aken: Scripta Metall. Mater., 30 (1994) 981. 
13)R. Gibala, A. K. Ghosh, D. C. Van Aken, D.J. Srolovitz, A.Basu, H.Chang, D. P. Mason and W. Yang: Mater. Sci. Eng., A155 (1992) 147.

14) Y. Suzuki, T. Sekino and K. Niihara: Scripta Metall. Mater., 33 (1995) 69.

15) Y. Harada, Y. Funato, M Morinaga, A. Ito and Y. Sugita: J. Japan Inst. Metals, 58 (1994) 1239.

16) K. Yanagihara, T. Maruyama and K. Nagata: Intermetallics, 3 (1995) 243.

17)K. Yanagihara, T. Maruyama and K. Nagata: Materials Transaction, JIM, 34 (1993) 1200.

18) C. Brukl, H. Nowotny and F. Benesovsky: Monatsh. Chem., 92 (1961) 967.

19)D. M. Shah, D. Berczic, D. L. Anton and R. Hecht: Mater. Sci. Eng., A155 (1992) 45.

20)A. Costa e Silva and M. J. Kaufman: Scripta.
Metall. Mater., 29 (1993) 1141.

21)A. Costa e Silva and M. J. Kaufman: Scripta. Metall. Mater., 31 (1994) 853.

22)A. Costa e Silva and M. J. Kaufman: Mater. Sci. Eng., A195 (1995) 75.

23) K. Niihara, R. Morena and D.P.H. Hasselman: J. Mater. Sci. Letter, 1(1982)13.

24) E. Parthe, W. Jeitschko, Acta Cryst., 19 (1965) 1031.

25) V. U. Kodash, P. S. Kisly and V. J. Shemet: High. Temp. Sci. 29 (1990) 143.

26) $Y$. Suzuki and K. Niihara: in preparation.

27) Y. L. Jeng and E. J. Lavernia: J. Mater. Sci. 29 (1994) 2557.

28) D. H. Carter, W. S. Gibbs, and J. J. Petrovic: Proc. of Ceramics Materials \& Components for Engines, 1988, 977. 